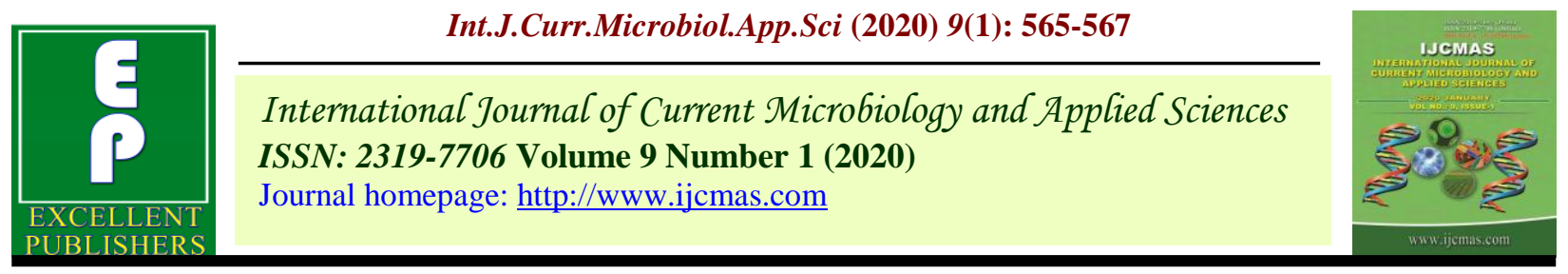

Case Study

https://doi.org/10.20546/ijcmas.2020.901.062

\title{
Management of Pre-Cervical Uterine Torsion in a Cow-Short Communications
}

\author{
Madhu Shivhare*, S. P. Nema, Lalit Sharma and Rohit Patidar \\ Department of Veterinary Gynaecology \& Obstetrics, College of Veterinary Science \& AH, \\ Mhow, M.P., India
}

\begin{tabular}{|l|}
\hline Ke y w or d s \\
Nondescript. \\
schaffer's method
\end{tabular}

A B S T R A C T

Pre cervical right side uterine torsion in a non descript (ND) cow was treated successfully by modified Schaffer's method and cow delivered a live female calf.

\section{Introduction}

Uterine torsion is the rotation of a pregnant uterus on its longitudinal axis, which leads to narrowing of the birth canal, causing dystocia. In bovine, it is a common major causes of bovine dystocia (Jeengar et al.,2015). It is categorized into left or right torsion according to the direction of rotation; mild, moderate or severe on the basis of degree and pre cervical of post cervical in term of position (Amer et al., 2008) Cows are thought to be more susceptible to uterine torsion than many other domestic animals due to their uterine instability resulting from the broad ligament attachments(Sloss and Dufty, 1980). It has also been considered that the way the cow stands upfrom lying in sterna recumbency may contribute to the occurrence of torsion (Noakeset al., 2009b). The routine treatment is rotating the uterus back into its physiologicalposition. Direct and indirect methods of re-torsion are available and used in accordancewith the conditions of clinical cases, in order to deliver the calf through vaginal deliveryor caesarean section (Erteld et al., 2014). The surgical treatment of uterine torsion bycaesarean section present numerous inconveniences, including riskof infection, damage to the internal organs and bleeding, as well as needing more time forrecovery. Hence, the non-surgical treatment by the "rolling method" is one of the mostpopular methods of detorsion (Noakes et al., 2001a).

\section{Case History and Clinical Observations}

A primiparous 5 yrs jersey cross breed cow which completed gestation period of 280 days with no premonitory signs of parturition with 
absence of relaxation of sacrosciatic ligament and failure of mammary gland development as per gestational stage was presented for treatment. the owner who got the cow examined by a local veterinarian with diagnosis of uterine torsion, who referred the animal to V. C.C., Mhow for management, the cow was brought to V. C. C., Mhow where a pre cervical right side uterine torsion was diagnosed by rectal palpation confirmed.

\section{Treatment and Discussion}

The cow was casted in right lateral recumbency with both fore and hind limbs are tied separately and detorsion was done by modified schaffer's method of rotation in same direction. the vaginal passage were examined after each rotation to check whether detorsion occur.after two rotation water bags comes out from uterus and cervix was fully dilated and fetal part and fetal head were palpable. the snares was applied on both fore limbs. Mild traction was applied on both fore limb and head. a live female calf was delivered by simple traction. the cow was administered with inj. Calcium Borogluconate (Mifex) $200 \mathrm{ml} \mathrm{S} / \mathrm{c}$ and $250 \mathrm{ml}$ slow I/ V, Inj. DNS - 3 liter, Inj. Dexamethasone - $15 \mathrm{ml}$, Inj. Ceftriaxone and Tazobactum (Intacef Tazo) -3 gm, and Bolus Oxytetracylcline -4 bolus $\mathrm{I} / \mathrm{U}$ foe 3 days.

Uterine torsion is a common condition causing dystocia in bovines. simple twisting is easily corrected under field conditions, but some cases referred to special clinics tend to represent the more extreme form of condition (Arthur et al., 1989). The degree of uterine torsion is considered as the emergency and surgery should be done as early as possible. It is necessary to evaluate the patient for their general health condition before starting the treatment, particularly the angle of twisting must be recognized. (Purohit et al., 2011).
Uterine torsion is stressful event as revealed by increased plasma cortisol concentration which increases further by $15-30 \%$ following detorsion of uterus through rolling of dam (Amer and Hashem 2008). Our finding are correlated with Prakash et al., 2014 and Bai et al., 2016.

\section{References}

Amer, H. A.., and Hashem, M. A. (2008). Relationship between clinical and biochemical picture of uterine torsion in egyptian buffaloes (Bubalus bubalis). The Intervet Journal of Veterinary Medicine., $4: 1$

Amer, H. A., Hashem M. A., Bader, A. (2008). Uterine twisting during pregnancy in buffaloes; relationship between clinical finding and biochemical indices. Journal of Applied Biological Science, 2 : 31- 39.

Arthur, G. H., Noakes, D. E., Pearson, H. (1989). Maternal dystocia : treatment. Fetal Dystocia : aeitology and incidence. In: Veterinary Reproduction and Obstetrics (Theriogenology). London, Bailliere Tindall, pp,:195310.

Bai, T., Diraviyam, T., Zhou, Z., Jiang, Z., Zhang, X. (2016). A comparative study of two uterine torsion correction methods in parturient cows. Veterinarski arhiV, 86 (6): 787-793.

Erteld, E., Krohn J., Dzhakupov, I. T., Wehrend A. (2014). Uterine torsion in cattle therapy and consequences for calf and cow. Tierärztliche Praxis Großtier, 42 : 297-303.

Jeengar, K., Choudhary, V. Maharia, S., Vivekanand, Purohit, G. N. (2015). A retrospective study on type and extent of uterine torsion in buffaloes. Research Journal for Veterinary Practitioners, 3: 25-28.

Noakes, D. E., Parkinson, T. J. England, G. C. 
W. (2009b). Maternal dystocia: causes and treatment. In: Veterinary Reproduction and Obstetrics, 9th ed. W. B. Saunders Company, USA, pp:232-246.

Noakes, D. E., Parkinson, T. J., England G. C. W. (2001a). Maternal dystocia: causes and treatment. Arthur's Veterinary Reproduction and Obstetrics. Elsevier Health Sciences, pp: 228-242.

Prakash, S., Selvaraju, M. and Ravikumar, K.
(2014). Clinical management of postcervical uterine torsion in a cow. Intas Polivet, 15 (2) : 241-242.

Purohit, G. N., Barolia, Y. Shekhar, C., Kumar, P. (2011). Maternal dystocia in cows and buffaloes: a review. Open Journal of Animal Science, 1: 41-53.

Sloss, V. and Dufty J. H. (1980). Dystocia. In: Handbook of Bovine Obstetrics. Baltimore, London,Williams \& Wilkins, pp: 108-111.

\section{How to cite this article:}

Madhu Shivhare, S. P. Nema, Lalit Sharma and Rohit Patidar 2020. Management of PreCervical Uterine Torsion in a Cow-Short Communications. Int.J.Curr.Microbiol.App.Sci. 9(01): 565-567. doi: https://doi.org/10.20546/ijcmas.2020.901.062 